\title{
The Empirical Study of Agricultural University Precise Help to the Poverty-stricken Village-A Case Study of Tianjin Agricultural University
}

\author{
Qiaoli Zhang \\ The science and Technology Department, \\ Tianjin Agricultural University \\ No.22, Jinjing Road, Xiqing District, Tianjin, 300384, \\ China \\ qlizhang@163.com
}

\author{
Xia Yang \\ The science and Technology Department, \\ Tianjin Agricultural University \\ No.22, Jinjing Road, Xiqing District, Tianjin, 300384, \\ China \\ tjqingqingcao@163.com
}

\begin{abstract}
In order to grasp the work of Tianjin Agricultural University in 500 poverty-stricken villages in Tianjin, we have summarized the work in the past three years. By analyzing organization work measures, concrete results and existing problems, we found that the agricultural universities have technical and talents advantages in the technical assistance work. At the same time, it was necessary to carry out the help work. We have put forward the work suggestion for a new round of technical assistance.
\end{abstract}

Keywords-Agricultural University; Precise help; Povertystricken village

\section{INTRODUCTION}

The research was sponsored by Tianjin social science community thousands of scholars' service grass-roots activities research project (2018) (Project No: 183320001)

In November 2013, Xi Jinping first made the important instructions of "seeking truth from facts, adapting to local conditions, classifying guidance and precise poverty alleviation "during his investigation in Xiangxi, Hunan province. Important thought of "precise poverty alleviation". In January 2014, the central office detailed the top-level design of the precise poverty alleviation work model, and promoted the idea of "precise poverty alleviation". In March 2014, during the deliberation of the NPC and CPPCC delegations, President Xi Jinping stressed the concept of precise poverty alleviation [1]. After careful research, planning, Tianjin municipal committee, municipal government printed "The implementation plan for supporting the development of 500 poverty-stricken villages" on October 31, 2014 [2]. The work of precise help povertystricken village was officially started. This plan proposes nine ways: promote the agricultural structure adjustment, promote "one village one agricultural product" characteristic industry development, promote the construction of agricultural facilities, promote agricultural technology support, promote agricultural science and technology demonstration, promote agricultural technology and farmers' skills training, promote the development of farmer cooperatives, promote agricultural product and marketing cohesion, promote rural financial service.

Under the guidance of Tianjin rural working committee, Tianjin Agricultural University has arranged for four groups to enter the poverty-stricken village and 24 technical experts. They have advantages in technology, focus on agricultural technology, and give consideration to other aspects of work instruction and technical training. We invest manpower and material resources in accordance with the established plan, and go all out to support work. After nearly three years of efforts, the technical assistance has achieved good social and economic benefits, and the experts' efforts have been recognized by villagers, town and municipal leaders. In 2015 and 2016, 5 experts in our school have been awarded the title of "excellent technical assistance worker", and 4 groups have been rated as "excellent technical assistance group"5 times.

\section{AgRICUltural UnIVERsities HaVe UNIQUE AdVANTAGES IN POVERTY ALLEVIATION}

The function orientation, special advantage and development needs of agricultural universities determine their irreplaceable role in precise poverty alleviation. Serving the countryside, carrying out precise poverty alleviation is not only the direct extension and expansion of the social service function of agricultural universities, but also the needs of its own development.

\section{A. Technical advantages}

Teaching a man to fish is better than giving him fish. For the poverty, the traditional poverty alleviation mode of "irrigation" and "blood transfusion" will lead to the individual doesn't ask for advancement, and should let him learn to "hematopoietic". The core competitiveness of agricultural universities lies in mastering advanced science and technology, agricultural universities can use its own advantages of science and technology, combining with the characteristics of resources in the poverty areas and for the poverty areas to develop new, highly effective characteristic industry, to help people out of poverty to get rich. Agricultural universities should play 
advantage, intensify training of science and technology, give full play to the role of "science and technology correspondent" and temporary staff, actively organize various types of management technology, practical technology, employment skills training, improve the comprehensive quality and labor skills of officials and the masses in rural areas.

\section{B. Talent advantages}

Precise poverty alleviation is a scientific, rigorous and comprehensive system project, which must be adapted to local conditions. Agricultural experts in various disciplines in universities are the intellectual reserve of technology support; guarantee the accurate support all aspects of the work. It is possible to allocate high-quality discipline to poor areas for decision-making consultation, design planning, and training education. They have the ability to implement "one village one policy ", or even "one family one policy ". At the same time, the vigor and intelligence resources of university students are also immeasurable power, we can encourage and guide university students to take advantage of social practice to participate in poverty alleviation.

\section{The necessity for agricultural universities to participate in precise poverty alleviation.}

The work of poverty alleviation is the concrete embodiment of the service society of agricultural universities and the realization of its own value, which is also the need of its own survival and development. It is well known that talent cultivation, scientific research, social service and cultural inheritance and innovation are the four major functions of universities [3]. In the current national poverty alleviation and development strategy of big background, how to use accurate support to promote the economy, society, culture and ecological construction in poverty areas, improve the poverty alleviation object self-development ability, help poverty people out of poverty to get rich, should become the primary functions of agriculture universities to serve the society. In addition, agricultural universities carry out precise poverty alleviation work, which is beneficial to the university's approach to society and provides a practical way for university students and teachers. It can improve the core competitiveness of universities. Through contact with the society to understand the needs of the society for university in the professional setting, curriculum planning, personnel training, scientific research, quality, etc., to make the university itself more targeted, and its development is more dynamic. Agricultural universities take this opportunity of development of higher education service function of rural poverty areas, both can solve the problem of higher education service in rural areas is insufficient, and improve the school's educational advantages, and enhance the strength of the school.

\section{THE MEASURES AND ACHIEVEMENTS OF ORGANIZATION}

A. The leadership attaches great importance to this work, and the organization is effective.

The smooth development of the assistance work is due to the high importance attached by the school leaders. At the start of work, school leaders focus on the work in person, called a number of pep rallies, coordinated the cooperation between the science and technology department, the publicity department, the organization department, the finance department and related colleges. We conscientiously organize and implement according to the requirements of the plan. Considering the different needs of the agricultural industry, we have selected 24 well-known experts from our school to participate in the technical assistance work, and also opened a column on the school's homepage to publicize the work.

In the help work, the vice President led the department of propaganda department, science and technology department, organization department and other departments responsible for the field inspection, supervised the technical assistance work, and guided the field work. On the one hand, they listened to the reports of the experts sent by the school, including the progress of the help, the specific measures taken, the specific problems and the next steps. On the other hand, according to the "one village one policy" economic development plan, they inspected the technical assistance work on the spot, learned the progress of the work in detail, and made clear the connection of the verification, analyzed and sorted out the existing problems.

\section{B. The implementation of technical assistance.}

24 experts from our school participated in the technical assistance work of 500 poverty-stricken villages. There were 117 poverty-stricken villages in 9 districts of Tianjin. Their work involved 8 industries: vegetables, flowers, forestry, fruit trees, animal husbandry and veterinary medicine, aquaculture, edible fungi and food.

After the assignment, the help expert immediately entered the village to carry on the assistance work. First of all, the help experts and the experts in each district have communicated with each other, and then contacted the village working group. Secondly, they conducted a survey on every poverty-stricken village, and based on the specific situation of each village and the discussion of village cadres and the village working group. Different technical assistance schemes were developed. Thirdly, they participated in the technical poverty reduction conference organized by Tianjin municipality and organized all members to study and discuss technical training and disseminating relevant technical data to farmers in poverty-stricken villages. Based on the formulation of the technical assistance scheme, the technical assistance groups ensured the "one village one policy" according to the requirements of the plan. 


\section{Specific methods of technical assistance.}

In accordance with the willingness of the poverty-stricken family, the help group chose the content of help and training, and carried out targeted training guidance. The effect is obvious and popular. Experts were faced with technical regulations and stimulation measures for farmers. In this way, the scientific and technological quality of science and technology demonstration families has been rapidly improved, and the leading role of science and technology training and technology enrichment has become increasingly prominent.

1) Make connection, establish contact and strengthen communication

The village committee members of each village and the village working group in the village have long worked in the village and were familiar with the situation of the village. It was the first step to make the connection with the village committee and the working group of the village. They were the bridge and the link between technical support group and farmers. By strengthening our contact and communication with them, we have grasped the technical needs and difficulties of planting farmers in time, and achieved twice the result with half the effort. At the beginning of the technical assistance work, the technical assistance group directly went to the village, discussed the work of technical assistance with the town and the village leading group, and cadres sent to the village for assistance. Our school has organized a group of experts to visit the poverty-stricken village for many times, and communicated with the director and secretary of the village, and made consultations with the village working group.

\section{2) In-depth investigation and research and elaborate plans}

In order to achieve the effect of technical support work, support groups set up by the professional and technical backbone team composed of experts, they all have the profound theoretical knowledge and rich production experience. According to their respective division of labor, they went deep into the poverty-stricken village to understand the basic situation and fully investigate. According to the district party committee of district government "one village on policy" plan, they worked out a series of practical work plan and specific technology support scheme, with the government and the local party committee, the village working group, and Village leaders. Thus, the work idea was clear, the direction was accurate.

\section{3) Always prepare, respond quickly, and pay a return visit} in time

Agricultural production has its particularity and uncertainty, and it is very likely that the farmers' annual income will be paid off once the problem is caused during the critical period of production. As a technical assistance expert, we should always be ready to give the timeliest help and support to farmers when they need them most. Many help groups set up a 24-hour response mechanism. Using QQ group, WeChat group and other modern communication methods, it was convenient to communicate with villagers and technical guidance in time to solve the technical problems quickly.

Professor Ban Litong who was responsible for edible fungi said: "Farmers live on their hands. Usually, a breeding mushroom greenhouse was probably more than half of their economic source.

Once there was a problem during the critical period of production, it was likely to cost the mushroom farmers a year's income. Experts as technical support, we should be always ready to provide the timeliest help and support at the time of planting mushroom farmers need most. Only in this way can the technical assistance work really make it possible to solve the problem for the poverty-stricken villages and farmers.

\section{4) "Team" support}

Technical assistance work has a lot of content. If we want to meet the needs of the villagers in production and operation, it is necessary for the group members to have strong technical skills, innovative spirit of selfless dedication, solidarity and cooperation. The industrialization development of agriculture was the crystallization of technology and operation wisdom, and the technical assistance work also needed to gather talents from all aspects to provide all-round service. Our school had the talent advantage of each industry, with the expert group leader, the project team carried out the joint help work. Different experts work together to solve problems with experts in other industries. In this respect, agricultural universities had their unique advantages in the industry technical reserves compared with other units.

Professor Xing Kezhi was mainly responsible for the help of 3 villages. In 2016, 3 villages have achieved remarkable results and achieved good economic, social and ecological benefits. The average net income of one village was 67,500 yuan $/ \mathrm{hm} 2$, which was raised by breeding penaeus vannamei.

Xing Kezhi also helped to contact the experts of other industries to fully mobilize the enthusiasm of the villagers. In this village, the average benefit of planting pepper is 60,750 yuan $/ \mathrm{hm} 2$. The village also planted pepper to achieve economic benefits of 4.05 million yuan; the economic benefit of planting tomatoes was 360,000 yuan, and the economic benefit of edible fungi such as mushroom and oyster mushroom was 108,000 yuan. Through their help, they raised the economic income of the poverty-stricken village. At the same time, it provided jobs for the surplus labor in the villages.

\section{EXISTING PROBLEMS}

\section{A. The time of technical assistance group members cannot be guaranteed.}

Wang Xiaoyi (2017) pointed out [4], the precise help is to complete the assigned task within the specified time. It required a full participation of the sporty type. In order to make the group work effectively, it was necessary to clearly define the objectives of the work, to equip it with the human and material resources, which were suitable to the target, and to ensure the time for the members of the technical assistance group. The members of the technical assistance group were responsible for teaching and research work in their respective units, so they couldn't help them anywhere, anytime. The relatively limited time they have to work in each village was an important factor restricting the effectiveness of technical assistance. 


\section{B. The understanding of farmers is poor and some concepts are difficult to change.}

The problem of farmers themselves was that subjective consciousness plays a role, which was also the key influencing factor of technical assistance. Yang Xiuli (2017) put forward [5], the level of villagers' self-government ability determined the progress of technical assistance work. Many farmers were not active in the work of help, and were not concerned with or cooperate with each other. They were too dependent on the work of the government, which made it difficult to carry out technical assistance work. The more poverty the farmers in the village, the more there were such problems. They were comfortable with the status quo and were accustomed to the traditional cultivation mode. And they were less active in accepting new things, updating knowledge and changing old ideas, which made it difficult for technical experts to carry out their work.

\section{Land limits}

Affected by the constraints of land and planning, it is difficult for the old and backward facilities in the village to be upgraded. Some villagers who wanted to work in the livestock farming industry were unable to implement because of land constraints. A single department couldn't solve the problem of land and land use characteristics, it required the government to coordinate multiple, provide convenience to technical support group and farmers and solve the problem of land circulation, accelerate the construction of rural land circulation platform, activate the rural land resources [6]. The transfer of rural collective land was the need of regional industrial structure upgrading and peasant employment transformation. Lin Nishang (2012) [7] pointed out that the rural collective land circulation in the government-led mode was more advantageous than the rural collective land circulation in the rural autonomous mode.

\section{SUGGESTIONS}

\section{A. Poverty-relief normalization}

The municipal government should normalize the assistance work, increased the investment, and led the farmers to change their ideas and improve economic, social and ecological benefits. Only the municipal government formulated the measures for the administration, to quantify their work, combined with their units of performance appraisal, reduced workload in their units, technical support staffs could be relieved to carry on the support work.

\section{B. Agricultural extension projects}

At present, the technical assistance experts only received a part of the traffic and the meal allowance. It was relatively difficult to carry out the work without a certain amount of funding. According to the actual situation of the difficult village, we could set up an agricultural extension project, and provided financial support. So that, the experts had the funds safeguard to carry out assistance work. At the same time, it was necessary to perfect and strengthen the agreement between the professional of technical assistance experts and the needs of the village or peasant households, so as to avoid the inconsistence between the experts' expertise and the village needs, and gave full play to their advantages and specialties.

\section{Integrate various resources and exert collective strength}

In the process of poverty alleviation, we should fully integrate all the resources we have obtained, solidify the resultant force, and then form a helping advantage.

Even if the experts' expertise was consistent with the technical requirements of the industry, it was inevitable that the technical support of various aspects would be necessary in the actual production process. For example, in the process of circulating aquaculture, the technology of aquaculture was required, and the technology of facility construction, environmental control, water treatment and other aspects were required. This required the collaboration of different professional experts. Because of their rich specialty, agricultural universities had unique advantages in technical talents, so as to facilitate the integration of technology and personnel integration in the precise help, and the work was relatively easy to carry out.

\section{CONCLUSION}

Along with the technical help group experts' footprints in the poverty-stricken village, the technical assistance of the influence was also expanding. In the city of Zunhua, Hebei province, which is located near the district of Jizhou, Tianjin, farmers who grew edible mushrooms also sought technical help from technical help group experts by telephone and network. Technical support group put the technology needs of farmers in the first place; they did not restrict the area of the help to Tianjin, and repeatedly provided the technical guidance and training for farmers in Zunhua city, Hebei province, to solve their technical requirements in a timely manner.

On the basis of summarizing the work of accurate help in the early stage, Tianjin launched a new round of work in poverty-stricken village in August 2017. The number of the village has doubled, and 1,000 villages have been set up to help With the previous experience of technical assistance, our school will keep abreast of the regional economic and social development and serve the modern agriculture of the city. Based on Tianjin and radiating the Bohai Sea, we will take the service of modern urban agriculture as our duty, and make unremitting efforts for economic construction, social development and scientific and technological progress. In the next step of technical assistance, we will sum up the experience, reflect on the standards, and organize experts to carry out the work better, and lead the farmers in our city to realize poverty alleviation. 


\section{REFERENCES}

[1] Anonymous. Accurate poverty alleviation https://baike.baidu.com/item/\%E7\%B2\%BE \%E5\%87\%86\%E6\%89\%B $6 \% \mathrm{E} 8 \% \mathrm{~B} 4 \% \mathrm{AB} / 13680654$ ? $\mathrm{Fr}=$ Aladdin [OL]. 2017-09-18. (In Chinese)

[2] General office of the CPC Tianjin municipal party committee, general office of Tianjin municipal people's government. General office the CPC Tianjin municipal party committee, General office of Tianjin municipal people's government issued the notice concerning the implementation plan of supporting the development of 500 poverty-stricken villages[Z] Tianjin party hall, No.22, 2014. (In Chinese)

[3] Li yongming. The necessity, advantages andrealization path of the precise povertyalleviation work of colleges and universities [J]. Journal of Yunnan Open University, 2016, 18 (4): 24-28. (In Chinese)

[4] Wang xiaoyi. Precise poverty alleviation and support for resident villages [J]. Journal of Chinese Academy of Governance, 2016 (3): 5662. (In Chinese)

[5] Yang xiuli, Xu baichuan. Study on the improvement of villagers' autonomy in the implementation of precise poverty alleviation policy [J] Journal of Nanjing Agricultural University (Social Science Edition), 2017,17 (4): 67-73. (In Chinese)

[6] Lin caiyun. Economic and trade development of rural poverty and precise poverty alleviation [J]. Agricultural Economy, 2017 (7): 42-44. (In Chinese)

[7] Lin nishang. Associated Mechanism among Rural Land Transfer, Industrial Development and Employment under Government Guidance - Practice in Rural Collective Construction Land Transfer at Near Suburb of Tianjin [J]. West Forum 2012, 22 (5): 1-8. (In Chinese) 